\title{
Vybrané bariéry inkluze sociálních pracovníků do multidisciplinárních týmů se zaměřením na vztah sociální pedagogiky a sociální práce
}

\author{
Zdeňka Dohnalová, ${ }^{\mathrm{a}}$ \\ Mirka Nečasová, ${ }^{\mathrm{b}}$ (iD \\ Robert Trbola
}

\begin{abstract}
Abstrakt: Cílem příspěvku je na základě shromážděných teoretických i empirických poznatků zodpovědět otázku: Jaké bariéry inkluze do multidisciplinárních týmů lze identifikovat ve vyjádřeních sociálních pracovníků - účastníků výzkumu? Autoři se nejprve zaměřují na objasnění základních pojmů, jako je inkluze do multidisciplinárních týmů a profesní identita, dále se věnují vztahu mezi sociální prací a sociální pedagogikou, která představuje jeden z oborů kvalifikačního vzdělávání pro sociální pracovníky, následně popisují výzkumnou strategii a výzkumný vzorek, který tvořilo 14 sociálních pracovníků. V analytické části prezentují vztah sociálních pracovníků ke své profesi a poté se zaměřuji na jejich zkušenosti s rolí sociálního pracovníka $v$ multidisciplinárních týmech. Bariéry inkluze sociálních pracovníků do multidisciplinárních týmů souvisejí s identitou profese a nízkou prestiží sociální práce.
\end{abstract}

Klíčová slova: multidisciplinární tým, spolupráce, bariéry spolupráce, inkluze, sociální práce, sociální pedagogika, pomáhající profese, profesní identita

\section{Selected barriers to the inclusion of social workers in multidisciplinary teams focused on the relationship between social pedagogy and social work}
Abstract: The aim of the article is to answer the following question based on theoretical research and empirical data: Which barriers to inclusion in multidisciplinary teams can be identified in the statements of social workers, i.e. the research participants? The authors first focus on the clarification of basic concepts such as inclusion in multidisciplinary teams and professional identity, then on the relationship between social work and social education, then latter of which is one of the fields of qualification education for social workers. At this point the research strategy and research sample, which consisted of 14 social workers, is described. In the analytical section the relationship of social workers to their profession is presented, following which focus is placed on their experiences regarding the role of social workers within multidisciplinary teams. Barriers to social worker inclusion in multidisciplinary teams were found to be related to identity issues regarding the profession along with the low prestige of social work. 
Keywords: multidisciplinary team, cooperation, barriers to cooperation, inclusion, social work, social education, helping professions, professional identity

\section{1 Úvod}

Součástí práce sociálních pracovníků je jejich participace v multidisciplinárních týmech, v nichž při řešení prípadu spolupracují pracovníci různých odborností (zdravotníci, duchovní, pedagogové, psychologové atp. $\left.{ }^{1}\right)$. Fungování multidisciplinárních týmů tedy vyžaduje spoluúčast pracovníků odlišných disciplín, kteří nahlížejí na životní situaci klienta především z pohledu svého oboru². Podmínkou multidisciplinárního př́stupu je dobrá znalost členů týmu o tom, jak oni sami i zástupci jiných oborů mohou přispět ke kvalitní a efektivní mezioborové spolupráci, což předpokládá pevné zakotvení v identitě jejich profese. Podle některých autorů však sociální pracovníci prožívají nejistotu pramenící z nejasné identity sociální práce, kterou se v moderní době nepodařilo plně etablovat jako profesi (Musil, 2013a). Tento fakt se může projevit v nejasném očekávání ostatních účastníků multidisciplinárního týmu od jejich role, ale i v tom, že sociální práce bývá považována za obor s poměrně nízkou prestiží, což může mít dopad na profesní sebepojetí sociálních pracovníků a může ovlivňovat vyjednávací sílu zástupců této profese v multidisciplinárních týmech. Důležitou roli hraje i skutečnost, že sami sociální pracovníci nemusejí být - co se týče pojetí sociální práce - jednotní, protože pracovní pozici sociální pracovník mohou podle Zákona o sociálních službách (Zákon č. 108/2006 Sb., 2019) vykonávat rovněž absolventi dalších oborů. Při práci $\checkmark$ multidisciplinárním týmu pak hraje roli i to, jak dalece tito pracovníci vnímají rozdíly nebo společné body sociální práce a jejich oboru kvalifikačního vzdělávání a jak konstruují svoji profesní identitu.

$\checkmark$ tomto textu se chceme zaměřit na překážky plné participace sociálních pracovníků v multidisciplinárních týmech tak, jak je spontánně uváděli účastníci výzkumu etických principů, hodnot a dilemat sociální práce. Cílem je na základě shromážděných teoretických i empirických poznatků zodpovědět otázku: Jaké bariéry inkluze do multidisciplinárních týmů lze identifikovat ve vyjádřeních sociálních pracovníků - účastníků výzkumu?

Předložený text prezentuje výstupy z první ucelené fáze projektu založeného na smíšeném kvalitativně kvantitativním výzkumném designu. Projekt je orientován na analýzu etických principů, hodnot a dilemat sociální práce. Téma, které prezentujeme v tomto článku - bariéry inkluze sociálních pracovníků do multidisciplinárních týmů - nebylo původně v centru našeho výzkumného zájmu, vynořilo se ze sesbíraných dat a podnítilo náš zájem.

Nejdřive se tedy zaměříme na objasnění základních pojmů, jako je inkluze do multidisciplinárních týmů a profesní identita, dále se blíže budeme věnovat vztahu mezi sociální prací a sociální pedagogikou, která představuje jeden z oborů kvalifikačního vzdělávání pro sociální pracovníky, následně popišeme výzkumnou strategii a výzkumný vzorek. $V$ analytické části se nejdřive zaměříme na vztah komunikačních partnerů k profesi sociální práce, a poté na jejich zkušenosti s rolí sociálního pracovníka $v$ týmech.

\section{Inkluze sociální pracovníků do multidisciplinárních týmů}

Gulová (2011) uvádí, že sociální práce se týká každého z nás a bývá nejefektivnější, když se na řešení problému podílí více subjektů společně. $V$ multidisciplinárních týmech působí odborníci zastupující určitou odbornost, určitý obor. Podle Němce a Šípa (2013, s. 12) je v novém pojetí vědy v centru snah

1 Mužský rod budeme z důvodu zjednodušení a přehlednosti textu používat pro označení mužů i žen. Zejména v analytické části textu budeme z důvodu zachování autenticity výpovědí informantek a informantů, sociálních pracovnic a sociálních pracovníků, užívat rod podle pohlaví informanta.

2 Nebo mohou prožívat sounáležitost s problémem, účastníky a přístupem mezioborové sítě (Musil, 2013b). 
věd společný problém. „Aby jej mohly jednotlivé vědy úspěšně řešit, musí spolu spolupracovat a zároveň čerpat informace a poznatky od sebe navzájem."

V multidisciplinárních týmech se využívá multidisciplinární způsob práce, což je přiměřené využití znalostí, zkušeností a nejlepší praxe více disciplín s překlenutím hranic jednotlivých poskytovatelů péče (zdravotní, sociální, neformální péče) za účelem redefinování, změny rozsahu a rámce poskytování zdravotních a sociálních služeb a dosahování řešení na základě lepšího společného porozumění komplexním potřebám klientů (pacientů) (NHS, 2014).

Pro účely tohoto textu vymezujeme multidisciplinární tým jako specifický typ pracovní skupiny tvořený odborníky z různých pomáhajících profesí, jejichž společným cílem je v procesu vzájemné spolupráce pomáhat klientovi řešit jeho obtížnou životní situaci. Inkluzi pak charakterizujeme jako stav, kdy je jedinec považován ve své pracovní skupině za insidera a má saturovanou potřebu sounáležitosti a zároveň vlastní jedinečnosti (Shore et al., 2011). Proces inkluze je spojen se snahou poskytnout členům jednotlivých profesí takové prostředí, kde budou moci uplatňovat svůj specifický př́nos. Jedná se tedy i o zrovnoprávnění všech zainteresovaných subjektů․ Inkluzi členů do multidisciplinárního týmu napomáhá funkční vytváření podmínek pro propojení za účelem budoucí spolupráce ${ }^{4}$, spolupráce samotná a také způsob, jakým tato dokáže utvářet změnu stavu věcí ve vztahu k vytyčeným cílům 5 . Inkluze je tedy zaměěena na práci s prostředím, v našem př́padě s celým multidisciplinárním týmem a prostředím, ve kterém tým působí.

Inkluze zahrnuje sociální interakci mezi sociálními pracovníky a členy dalších pomáhajících profesí. V centru naší pozornosti stojí spolupráce sociálních pracovníků mezi sebou a především se zástupci dalších pomáhajících profesí v multidisciplinárním týmu. Rozhodující je pro nás aspekt spolupráce sociálních pracovníků se zástupci jiných profesí bez ohledu na dobu jeho trvání či intenzitu společných interakcí. Spolupráce, která nás zajímá, mưže probíhat (nebo jednorázově proběhnout) tvárí v tvář, ale i distanční formou.

Cílem působnosti multidisciplinárního týmu je pomoc klientovi, který se nachází v obtižné životní situaci. Předpokládá se, že setkání a spolupráce odborníků v různých oblastech poskytne komplexnější náhled a tím i odpovídající pomoc šitou na míru klientovi a jeho situaci. Tito odborníci nicméně musejí mít jasnou představu o tom, jak může každá jedinečná disciplína k naplnění tohoto cíle přispět.

\section{Profesní identita sociálních pracovníků}

U úvodu jsme poukázali na skutečnost, že sociální pracovníci mohou prožívat nejistotu pramenící z nejasné identity sociální práce, takže pracovníci se $v$ dnešní postmoderní tekuté době nemohou o její základy s jistotou opř́t (Nečasová, Dohnalová, \& Rídlová, 2012). Tento fakt se projevuje i v nejasném očekávání ostatních účastníků multidisciplinárního týmu od jejich role. Nyní se tedy zaměříme na koncept identity.

Identita bývá charakterizována prostřednictvím tří hlavních faktorů (Webb, 2017), kterými jsou: (1) osobitost: odkazuje na profesní hodnoty dané profesní skupiny (holistický přístup v sociální práci), (2) prestiž a legitimita profesní skupiny, (3) význam pro ostatní stojící mimo tuto profesní skupinu (out-group).

Podobně Wiles a Vicary (2019) uvádějí, že profesní identitu lze charakterizovat jednak prostřednictvím žádoucích standardů a kompetencí vyjadřujících dobrou praxi, jednak prostřednictvím objasnění kolektivního chápání smyslu (toho, co znamená být sociálním pracovníkem v kontextu specifických oblastí praxe). Další způsob porozumění identitě je pak založený na rozpoznání subjektivního významu

3 Srovnej Bartoňová a Vítková (2016).

4 Zde v rámci multidisciplinárních týmů.

5 Zde forma sociální práce scílem změny životní situace klienta, která je prostřednictvím sociální práce nabízena. 
identity pro jednotlivé sociální pracovníky. Právě tento třetí přístup jsme pro porozumění identitě a tedy i podobě spolupráce a začleňování do multidisciplinárních týmů ve výzkumu zvolili.

Autoři se také zaměřují na nebezpečí ztráty identity. Např. Wiles a Vicary (2019) si v souvislosti s vlivem organizačního kontextu kladou otázku, zda se spolupráce pracovníků z více pracovišt' (multi-agency working) může stát hrozbou pro zachování svébytné identity profese sociální práce. Uvádějí příklad eklektického př́stupu k identitě, kdy sociální pracovníci působící ve zdravotních službách popisovali svoje různorodé role: často vykrývali oblasti, které nebyly obsazeny jinými profesionály. Vykonávání fluidní a flexibilní směsice úkolů (často i mimo pomoc zaměřenou přímo na klienta) bránilo tomu, aby se v sociální práci vyvinula osobitá a dobře pochopitelná profesní identita, která se pro práci v multidisciplinárním týmu zdá být nezbytná. Webb (2017) také upozorňuje na to, že eroze hranic mezi profesemi může vyústit $\mathrm{i} v$ to, že sociální pracovníci mohou být označeni za neprofesionály (pojímáme-li profese $v$ klasickém slova smyslu). Jednotlivé profese totiž mají s různou přesností vymezeny svoje hranice, privilegia i zdroje, které mohou čerpat. Je tedy těžké dosáhnout efektivního partnerství např. mezi sociální a zdravotní prací především s ohledem na rozdíly v moci a soutěžení mezi profesemi na jednom teritoriu. Webb (2017) dodává, že sociální práce má poměrně vratkou pozici i s ohledem na to, že pomáhá klientům, kteří mají nízký status.

Toto téma rozvijí například Clark (2000), podle jehož názoru je sociální práce každodenně konfrontována s tím, že musí obhajovat svoji existenci. To je dáno více faktory, jako jsou např́klad:

- povaha sociální práce a její komplexnost (sociální pracovníci často operují na hranicích různých oborů, např. nejsou vzděláním pedagogové, ale nerezignují na výchovné prvky při práci s klientem; takto bychom mohli uvést příklady dalších oborů, s jejichž znalostmi sociální pracovníci do určité míry pracují),

- ambivalentní postoj společnosti týkající se významu a potřebnosti sociální práce (sociální pracovníci pracují s cílovými skupinami, kterým by se běžní občané raději vyhnuli, např. práce s lidmi se závislostmi, bez domova, s různými handicapy apod.),

- společenský kontext (rychlá a průběžná změna hodnot a na náhledy na klasické instituce jako je např. rodina v postmoderní době).

V neposlední řadě se na nejistotách podílí i úroveň vzdělávání a požadavky kladené na absolventa oboru. Profesi sociálního pracovníka legislativně vymezuje Zákon o sociálních službách (Zákon č. 108/2006 Sb., 2019). Ten určuje kromě jiného podmínku vzdělání na vyšší odborné nebo vysoké škole, původně v oblasti sociální práce, nicméně v současném znění připouští i vzdělání v oboru sociální pedagogiky, práva, speciální pedagogiky ${ }^{6}$. To má dopad na identitu profese, protože pracovníci mohou být výrazněji zakotveni a identifikováni s oborem jejich kvalifikačního vzdělávání než se sociální prací samotnou. Společným bodům a odlišným bodům sociální práce a sociální pedagogiky se budeme krátce věnovat $v$ další kapitole.

\section{Blízko od sebe - vzájemný vztah sociální pedagogiky a sociální práce}

Vztahu sociální práce a sociální pedagogiky se v českém prostředí věnují např. Gulová (2011), Kraus (2011), Kraus s Hoferkovou (2016) nebo Kaplánek (2013).

Oba obory, sociální práce i sociální pedagogika, jsou jak akademickými disciplínami, tak i oblastmi praxe. Jak uvádí Šíp (2013) pedagogika přešlapuje na pomezí mezi praktickou pedagogikou a vědou o výchově a obě skupiny pedagogů na sebe hledí s nedůvěrou. Napětí mezi světem teorie a praxe panuje také v sociální práci, proto je přímo v definici sociální práce deklarováno, že sociální práce zahrnuje obojí: je to na praxi založená profese a akademická disciplína (IFSW, 2019).

Společné je rovněž zaměěení obou disciplín na osoby nacházející se v obtížných životních situacích. Přadka $(2002$, s. 9) upozorňuje, že adjektivum sociální je většinou chápáno jako „pomoc poskytující

\footnotetext{
6 Srovnej Nečasová a Křištan (2018).
} 
potřebným, pričemž tato potřebnost může mít různý původ a príčinu i soubor charakteristik: ,potřebni" jsou obecně chápáni jako lidé určitým zpưsobem znevýhodnění vưči průměrným (...)." Kraus $(2011$, s. 30) však upozorňuje, že sociální pedagogika se zaměřuje na celou populaci, kterou chce vést ke zdravému způsobu života, zatímco sociální práce má svou cílovou populaci „přefiltrovanou“. „Oním filtrem je prítomnost určité situace, která je definovaná jako sociálně problémová."

Jak sociální pedagogika, tak sociální práce se zčásti překrývají, nebot' obě mohou napomoci změnit životní situaci člověka (Kaplánek, 2013). Obě disciplíny však k tomuto cíli jdou po své vlastní stezce. Zatímco sociální pedagogika je více zaměřena na výchovně-vzdělávací oblast, jednou ze základních charakteristik sociální práce je holistický pohled na životní situaci klienta, který berou sociální pracovníci v potaz při posouzení jeho životní situace. Podle Musila $(2004$, s. 18) je sociálním pracovníkům společné, „že předmětem jejich pozornosti je celková situace klienta, že se snaží prímo či neprímo přispět k tomu, aby klient zvládl širší škálu bariér, a že značnou část služeb, které klient potřebuje, zprostredkovávají a sami je prímo neposkytuji. "Sociální pracovníci tedy mohou být těmi, kdo v rámci mezioborové spolupráce přizvou sociální pedagogy (i naopak). U obou disciplín je kladen důraz na schopnost týmové spolupráce. Šíp s Němcem (2013, s. 12) uvádějí, že sociální pedagogika spolupracuje („tu více tu méně") se svými hraničními disciplínami (explicitně jmenují sociologii, sociální psychologii, antropologii, etnologii, ekonomii, filosofii, nikoliv však sociální práci) „a do společného portfolia řešení problémů přináší dimenzi pedagogického působení, které vede k optimalizaci sociálních vztahů mezi jedincem a společenstvím / společností, mezi společenstvími navzájem a uvnitř společnosti jako celku."

Odlišnosti obou disciplín shrnuje i Gulová (2011), která uvádí, že v našich podmínkách vnímáme sociální práci jako intervenci do náročné situace klienta, jenž často není motivován ke změnám. Sociální pedagogika pracuje spíše s prostředím, které člověka obklopuje. Věnuje se aktivizaci jedince, zejména v oblasti prevence. Podle Musila se nicméně sociální práce zaměřuje na klienta i na prostředí, ve kterém klient žije, protože cílem sociální práce je „pomoc klientům zvládat nesnáze v jejich interakcích se subjekty v jejich sociálním prostředi" (Musil, 2013b, s. 512). Odkazuje tak na sociálně ekologickou perspektivu v sociální práci a na koncept sociálního fungování Bartlettové.

Oním „od sebe“ máme na mysli rovněž vzdělávání budoucích sociálních pedagogů v oboru sociální práce. Je možné, že někteří sociální pedagogové (respektive vzdělavatelé v oblasti sociální pedagogiky) se mohou cítit ohroženi oborem sociální práce, který sice rovněž patří mezi méně etablované profese, ale $v$ zákonech má již více ukotvenou pozici ${ }^{7}$. Nepokoj mezi vzdělavateli v sociální pedagogice způsobily části návrhu připravovaného Zákona o sociálních pracovnících, týkající se vymezení odborné způsobilosti sociálních pracovníků. Asociace vzdělavatelů v sociální pedagogice vyjádřila své výhrady k faktu, že absolventi oboru sociální pedagogika by již podle daného zákona nemohli nacházet uplatnění na pracovních pozicích sociálních pracovníků (Hladík, 2019). Mezi pěti body zdůvodnění zaznívá na druhém místě: „Obsahy vzdělávání v sociální pedagogice na českých vysokých školách respektují minimální standardy vzdělání v sociální práci formulované Asociací vzdělavatelů v sociální práci, rozsah odborné praxe i doporučené spektrum činností v sociálních institucích." (Hladík, 2019, s. 3) V nesouladu s tímto tvrzením jsou ale zveřejněné Standardy vzdělávání v oblasti sociální pedagogiky pro jednotlivé typy studijních programů vydané Asociací vzdělavatelů v sociální pedagogice (Hladík, 2019). Např. v preambuli tohoto dokumentu zaznívá (tamtéž, s. 2): „absolventi programu Sociální pedagogika (by) měli mít takové teoretické znalosti z pedagogiky, psychologie, sociologie, práva, filosofie, teorie řizení a metodologie, takové komunikační a psychosociální dovednosti, takové organizační schopnosti, aby byli způsobilí k výkonu práce v sociálně pedagogické oblasti (...)." Sociální práce zde překvapivě není zmíněna, ani další disciplíny Minimálního standardu vzdělávání v sociální práci ASVSP (dále jen MS ASVSP), které mají školy za povinnost plnit

7 Srovnej Zákon o sociálních službách 108/2006 Sb. (Zákon č. 108/2006 Sb., 2019) a Zákon o pedagogických pracovnících 563/2004 Sb. (Zákon č. 563/2004 Sb., 2019).

8 Srovnej ASVSP (2019). 
Gulová (2011) naopak upozorňuje na opačný extrém, než na jaký jsme poukazovali výše. Totiž, že některá pracoviště sice mají obory s názvem sociální pedagogika, ale většina jejich předmětů čerpá ze sociální práce.

Působení absolventů sociální pedagogiky na pozici sociálních pracovníků je v současné době zcela legitimní. Logicky by se však dalo očekávat, že ve vzdělávání těch sociálních pedagogů, kteří mají ambici pracovat na pozici sociální pracovník, bude více akcentována edukace v oblasti sociální práce a samozřejmě naplňován MS ASVSP. Jedná se o jednu z cest „péče“ o identitu profese sociální práce, ale i sociální pedagogiky. Explicitní přihlášení sociálních pedagogů k sociální práci i v oficiálních dokumentech by podle našeho názoru bylo rovněž vyjádřením vzájemného respektu, což je jednou z podmínek úspěšné mezioborové spolupráce.

\section{Bariéry inkluze sociálních pracovníků do multidisciplinárních týmů}

Výše v textu jsme zmiňovali bariéry inkluze sociálních pracovníků do multidisciplinárních týmů v souvislosti s profesní identitou, prestiží profese a vzděláváním sociálních pracovníků.

Níže v textu se zaměříme i na situace, kdy jsou sociální pracovníci součástí multidisciplinárních týmů na jiném než domácím poli. Uvědomujeme si, že pokud např. pracovníci sociálně právní ochrany dětí svolají prípadovou konferenci ${ }^{9}$, kterou některý z nich sám vede, nemusí nastat žádná bariéra $v$ začlenění sociálních pracovníkư ${ }^{10}$ do tohoto týmu, nebot sociální pracovníci jsou v tomto prípadě těmi, kdo hrají na vlastním hřišti. Jiná situace však může nastat např. ve zdravotnických či pedagogických zařízeních, kde může dominovat aspekt dané oblasti zaměření.

Budeme si všímat také vzájemných očekávání členů multidisciplinárních týmů od spolupráce, přičemž v analytické části zprostředkujeme pohled sociálních pracovníků a jejich zformulovaná očekávání. Může se stát, že jednotliví účastníci multidisciplinárních týmů předpokládají, že všichni ví, co je obsahem práce (jaké jsou profesní kompetence) zástupců jednotlivých profesí - jinak řečeno, co mohou ostatní nabídnout v procesu spolupráce. Tato nevyřčená očekávání se však mohou lišit a jejich nesoulad může způsobit bud' to, že se tým vůbec nevytvoří nebo funguje se značnými problémy. Jak však konstatuje Truhlářová (2013), oblast vymezení profesních kompetencí v sociální práci ztěžuje skutečnost, že neexistuje jediná všeobecně platná taxonomie profesionálních kompetencí. Skutečností podle autorky zůstává, že se doposud nepodařilo vyvinout jednotnou, odborníky obecně príímanou taxonomii profesních kompetencí sociálního pracovníka. Kaplánek (2013, s. 506) uvádí, že vzdělání potřebné k vykonávání práce sociálního pracovníka vyžaduje poměrně hluboké znalosti z celé oblasti společenskovědních disciplín a také rozvoj specifických znalostí potřebných pro sociálního pracovníka. „V rámci procesu určování priorit došlo k tomu, že z kurikula prípravy sociálních pracovníků vymizela pedagogická průprava, což se ukazuje v současné době jako nedostatek (...)." Tento nedostatek se může projevovat i v přípravě na začleňování do multidisciplinárních týmů, ale i při práci sociálních pracovníků s dětmi a mládeží, jak dále upozorňuje Kaplánek (2013). Další z bariér tedy může být i nedostatečná příprava budoucích sociálních pracovníků na práci v multidisciplinárních týmech.

Venglářová a kol. (2011) se zaměřují na další bariéry týmové spolupráce:

- pracovník přesně nezná obsah a rozsah své role,

- pracovník má jiná (někdy skrytá) očekávání od pracovní pozice,

- pracovník nemá pro výkon role dostatečné vzdělání a předpoklady.

\footnotetext{
Prípadová konference je jednou z forem multidisciplinárního týmu.

10 Respektive pracovníků sociálně právní ochrany dětí.
} 


\section{Metodická část}

Předložený text prezentuje vybrané výstupy z první ucelené fáze výzkumného projektu založeného na smíšeném kvalitativně kvantitativním výzkumném designu. Niže prezentovaná zjištění vycházejí z kvalitativního šetření, které proběhlo na přelomu roku 2018/19 a bylo zaměřeno na hodnoty, obtí̌né situace a dilemata, se kterými se sociální pracovníci ve své praxi setkávají. Celkem jsme vedli 22 rozhovorů se sociálními pracovníky. Výběrový soubor byl sestaven na základě kriteriálního výběru, přičemž kritéria pro zařazení do vzorku byla následující: působnost v rámci vybraného kraje, práce na pozici sociální pracovník a zahrnutí pokud možno co nejširší variability zařízení tak, aby bylo možné postihnout hodnoty a dilemata sociálních pracovníků působících např́íc zařízeními, cílovými skupinami i resorty. Dalším kritériem bylo vyjádření souhlasu súčastí ve výzkumu. Jednotlivá zařízení, v nichž informanti pracují, byla vybrána losem. Ne všechny informanty z výběrového souboru jsme ovšem do výzkumného vzorku (viz níže) zařadili, nebot' někteří nehovořili o bariérách inkluze do multidisiciplinárních týmů. Dané téma totiž nebylo původně v centru našeho výzkumného zájmu, vynořilo se ze sesbíraných dat. $V$ tomto textu tedy pracujeme s vybranými poznatky z rozhovorů.

Technikou sběru dat se staly polostrukturované rozhovory. Po sérii identifikačních otázek, kdy jsme zjištovali mimo jiné kvalifikační vzdělání sociálních pracovníků, jsme se zaměřili na vzdělání již konkrétně voblasti etiky a vztah informantů k sociální práci. Následovala sada otázek věnovaná hodnotám a etickým dilematům. Při formulaci otázek $\mathrm{k}$ posledně jmenovanému okruhu jsme vycházeli z dilemat formulovaných Musilem (2004), který využívá rozdělení na všední dilemata raadových pracovníků a na strategická dilemata (a jejich řešení řadovými pracovníky).

\section{Výzkumný soubor}

Níže představíme výzkumný soubor 14 informantů zařazených do této fáze výzkumu. U vybraných informantů, absolventů sociální pedagogiky, uvádíme jejich vystudovaný obor; ostatní jsou absolventy mateřských oborů sociální práce a speciální pedagogiky. Konkrétní obory neuvádíme z důvodu ochrany anonymity informantů (obor, který vybraný informant absolvoval, je v současnosti možné vystudovat pouze na jedné ze škol sociální práce a $v$ kombinaci s pracovní pozicí bychom danému účastníku výzkumu nemohli zajistit anonymitu). $Z$ téhož důvodu neuvádíme ani délku praxe a další identifikační údaje o informantech.

- Sociální pracovnice městského úřadu (R1)

- Sociální pracovnice městského úřadu (R2) - absolventka sociální pedagogiky

- Pracovnice OSPOD (R3)

- Pracovník úřadu práce - oddělení hmotné nouze (R4)

- Sociální pracovnice $v$ hospici (R5)

- Zdravotně-sociální pracovnice v nemocnici (R6)

- Zdravotně-sociální pracovnice v nemocnici (R7) - absolventka sociální pedagogiky

- Zdravotně-sociální pracovnice $v$ nemocnici $(R 8)^{11}$

- Zdravotně-sociální pracovnice v nemocnici (R9) - absolventka sociální pedagogiky

- Sociální pracovnice $v$ dětském domově (R10) - absolventka sociální pedagogiky

- Sociální pracovník z uprchlického zařízení (R11)

- Sociální pracovník věznice (R12)

- Sociální pracovnice vpedagogicko-psychologické poradně (R13) - absolventka sociální pedagogiky

- Sociální pracovnice střediska výchovné péče (R14).

11 Informanti R6, R7, R8 jsou ze stejného pracoviště. 


\section{Analytická část}

Identifikované bariéry inkluze sociálních pracovníků do multidisciplinárních týmů souvisejí s identitou profese. Názvy subkapitol $v$ této části článku označujeme kategoriemi, které jsme určili v procesu kódování. Některé z kategorií jsou označeny in vivo kódy, tedy označeními, které v průběhu výzkumných rozhovorů použili samotní účastníci výzkumu.

\section{Vztah informantů k sociální práci}

\section{Sociální práce jako popelka}

Jak je již uvedeno výše, do scénáře rozhovoru jsme zařadili otázky zjištujující vztah informantů ke svému povolání. Účastníci výzkumu opakovaně přirovnávali sociální práci k Popelce. Dívky, která je symbolem nedocenění, odstrkování a útlaku. A Popelkou mezi ostatními vědními obory a pracovními pozicemi je podle některých účastníků výzkumu právě sociální práce.

„No my víme, že ta sociální práce je taková popelka, že jo. Je popelka, jak na těch úřadech, tak všude jinde, co si budeme vykládat."(R1)

Nedoceněného postavení sociální práce se $v$ rozhovoru dotkla i jiná účastnice výzkumu, která komparovala postavení sociálních pracovníků ve Velké Británii a České republice.

„(Ve Velké Británii) je sociální pracovník jako fakt jako skoro jako někdo jako právník nebo jo, že tady to tak vůbec jako není, je to škoda, je to určitě škoda, ale vím, čím to je? Nevím." (R3)

Z výpovědi je zjevné, že povolání právníka řadí mezi prestižní a vyjadřuje smutek nad realitou z naší země (,je to škoda"). Z výpovědi zaznívá i jistá bezmoc; pokud nevím, čím je situace způsobena, hledá se těžko zpưsob nápravy.

Na bezmoc z omezených možností intervence sociální práce do životní situace klienta poukazuje další z účastníků výzkumu:

„No tak myslí si (společnost), že jsme trošku zbyteční (...). Jelikož vidí, že ti lidi jsou prostě (...) neprizizpưsobiví, tak si myslí, že jsme k ničemu, že tam nemáme šanci co změnit. Že by se asi mělo změnit něco nad tím, než jako my osobně." (R4)

Sociální práci v pozici popelky jsme identifikovali i v souvislosti se vzděláváním budoucích sociálních pracovníků na jiných než mateřských oborech. Sociální pracovnice městského úřadu, absolventka magisterského studia sociální pedagogiky, nám v průběhu výzkumného rozhovoru sdělila:

„A škola, tam byla sociální práce jenom hodně okrajově. Spíš, co mně teda dala, jsem si ted'vzpomněla, tak ted' máme pár psychiatricky nemocných klientů v poslední době a tam spís znalost těch poruch a psychické aspekty. Spíš teoretické vědomosti. Jako co se týká sociální práce, vyplňování formulárù, dávky a to všechno bylo samostudium až po škole, až v praxi. Protože to se taky hodně mění, tak to stejně nejde nějak nastudovat. To až škola ,život', opravdu praxe." (R2)

Tato žena oceňuje, že i když se v průběhu své vzdělávací dráhy př́liš nedozvěděla o sociální práci, získala v rámci studia sociální pedagogiky informace, které nyní může aplikovat vpraxi. Vzdělání v sociální práci považuje v podstatě za zbytečné (,tak to stejně nejde nějak nastudovat"). Výroky pracovnice nasvědčují, že ztotožňuje sociální práci pouze s její administrativní funkcí („vyplňování formulárư, dávky“). Tento zúžený pohled může být dán různými důvody (např. i zavedenou kulturou organizace nebo nedostatkem znalostí o sociální práci).

\section{Sociální pracovnice jako paní Zubatá z filmu Kolja}

Několikrát v průběhu výzkumných rozhovorů zaznělo, že lidé z okolí informantů přirovnávají sociální pracovníky $\mathrm{k}$ postavě $z$ filmu Kolja paní Zubaté: ženě uspěchané, odměřené, formálně vystupující a snažící se nepř́ijemný prípad co nejdřive uzavřít. Paní Zubatá symbolizuje pouze spiše formální 
kontrolu než pomoc člověku v obtížné životní situaci, s minimem osobní angažovanosti a zájmu. S tímto přirovnáním se někteří sociální pracovníci, účastníci našeho výzkumu, setkávají opakovaně v situacích, kdy představují svoji profesi.

S pohledem na sociální pracovnice typu paní Zubaté nesouhlasí informantka namítajíc:

„(...)že sociální pracouník je vysokoškolák ${ }^{12}$, který se celoživotně vzdělávád ${ }^{13}$, to si myslím, že většina populace netuší jo, prostě ještě furt zůstává sociální pracovnice Zubatá, skoro jako prototyp." (R5)

Další komunikační partnerka poukázala dále na jeden ze zaběhlých stereotypů, totiž, že sociální práce je $v$ očích veřejnosti hodně spojená pouze s vybranými, většinou "dobře" viditelnými ${ }^{14}$, cílovými skupinami, $v$ tomto prípadě se sociálně-právní ochranou dětí.

„V mnoha směrech si myslím, že to je takové pořád v uvozovkách strašák z těch filmů, 'príjde sociální pracovnice paní Zubatá'. (...) to je takový v povědomí hodně (...) a mám pocit, že to je spiš spjatý právě s takovou tou péčí o to dítě, ta sociální práce." (R9)

\section{Role sociálních pracovníků v multidisciplinárním týmu}

\section{Sociální pracovník jako pomocník pracovníků ostatních pomáhajících profesí}

Níže již budeme sociální pracovníky představovat jako držitele jisté specifické role v multidisciplinárním týmu, jak vyplynulo z výzkumných dat. Někteří informanti mluvili o těchto rolích spontánně, jiní se k mezioborové spolupráci vyjadřovali nejčastěji v rámci zodpovídání otázky na jedno z etických dilemat sociálních pracovníků: „Kdy je třeba prosazovat zájem sociální práce a kdy je třeba brát v úvahu i zájmy jiných oborů a společný zájem vyjednat? "15 Identifikované role v sobě přitom zahrnují rizika určitých bariér, které chceme identifikovat a pojmenovat.

Sociální pracovnice ze střediska výchovné péče charakterizuje svoji pracovní pozici v týmu následovně: „No asi pomocník právě s tou administrativou (...). Že to (...) pomáhám zjednodušit (...). Nebo třeba když nabírám obědy (...), tak tím zase zjednodušuju tu práci...je to efektivnějši, když ten (jméno etopeda) je tady s nimi u stolu, než aby tady to nabíral někde za okýnkem (...). Takže usnadnění a nějaká pomoc. Protože kdyby do toho třeba měli dělat finance, tak by prostě nevím, jak by zvládali. Takže to je takový rozdělení těch činností." (R14)

Z výpovědi vyplývá, že toto své postavení sociální pracovnice jako „pomocnice ostatních“ akceptuje, přijímá jako realitu a racionalizuje jej jasně definovaným přínosem pro ostatní. Popisovaná náplň její práce je přitom v některých aspektech v rozporu s činnostmi sociálních pracovníků, které vymezuje zákon (Zákon č. 108/2006 Sb., 2019), a odpovídá spíše náplni práce pracovníka v sociálních službách (např. nabírání stavy). Pracovník $v$ sociálních službách však $v$ daném středisku výchovné péče zaměstnán není a daná sociální pracovnice zjevně jeho práci vykrývá. Komunikační partnerka dala najevo, že v prrímé práci s klientem považuje za důležitější osobu etopeda (,je to efektivnějši"). Těžiště její práce leží především v administrativě. Tato skutečnost se podle slov účastnice výzkumu negativně projevuje např. na supervizích: „Jelikož já takhle moc neprijdu do kontaktu s těma klientama, tak nemám k tomu co úplně ríct." Tato skutečnost může komplikovat její zapojení do mezioborové spolupráce, kdy se podle svých slov cítí být vyčleněna z diskuse o životní situaci klienta (, nemám $k$ tomu co úp/ně říct").

12 může být i absolvent vyšší odborné školy - srovnej Zákon o sociálních službách (Zákon č. 108/2006 Sb., 2019).

13 Viz např. Etický kodex Společnosti sociálních pracovníků ČR („Společnost“, 2019).

14 Kromě dětí se jedná o osoby bez prrístřeší, osoby se závislostí na alkoholových a nealkoholových drogách či příslušníky etnických menšin.

15 Srovnej Musil (2004). 
Roli „pomocnice“ lékaře akceptuje i zdravotně-sociální pracovnice v nemocnici:

„Já (...) jsem, bych řekla, takovou pravou rukou lékaře, takže hodně to záleží na požadavcích nebo zadání toho lékaře. Pokud zavolá lékař ,tohodle ted'ka chci řešit, je potřeba tohlencto vyř́idit, vykomunikovat, zajistit', tak vlastně pro mě je to prvořadé zadání tady. "(R6)

Zadání úkolů zdravotně-sociální pracovnice je tedy v kompetenci lékaře, vedoucího týmu, s nímž komunikační partnerka o své pracovní náplni nepolemizuje. Lékař je pro ni autoritou, na jehož úsudek se spoléhá. Možnost autonomního rozhodování této účastnice výzkumu je omezeno, aniž by to na vědomé úrovni, kterou nám v průběhu výzkumného rozhovoru zprostředkovala, vnímala jako újmu.

Obě výše citované ženy přijímají svoji roli pomocnice ostatních bez námitek. Při analýze jsme však tuto kategorii zařadili do bariér týmové spolupráce, nebot jsme přesvědčeni, že popisovaný přístup může být překážkou v nabídce široké škály činností sociální práce, na které už, z pochopitelných důvodů, nezbývá čas a zadavatelé úkolů sociálním pracovníkům (případně zdravotně-sociálním pracovníkům) možná ani nevědí, že tito odborníci mohou nabídnout širokou škálu služeb. Sociální pracovník se může stát pomocníkem, který udělá to, na co ostatní nemají čas, co nevyžaduje odbornost, popř. se neví, kdo jiný by daný úkol měl vykonat. Tato skutečnost se ve výzkumných rozhovorech objevila vícekrát, např. „potom děláme práci, kterou by zvládli udělat jiní z mého pohledu“ (R11). Pro některé sociální pracovníky se může dokonce jednat o degradaci, nebot' jsou konfrontováni s požadavky na vykonávání činností (servírování jídla, úklid, atp.) nevyžadujících kompetence získané v rámci terciálního vzdělávání.

\section{Sociální pracovník jako ten, který dělá „černou práci“}

S rolí sociálního pracovníka jako pomocníka souvisí další kategorie: sociální pracovník jako ten, který dělá „černou práci“. Své pojetí tohoto typu práce prostřednictvím přirovnání z fotbalového prostředí přináší pracovník z věznice.

„My děláme tu černou práci. To máte jak ve fotbale, že máte černou práci jako nahrát tomu útočníkovi prímo na gól. A trefit se do té branky je sice kumšt, ale musíte vypracovat tu šanci." (R12)

V tomto pojetí se „černá práce“ podobá práci spočívající v pomáhání ostatním členům týmu (viz výše). Daný účastník výzkumu vyjadřuje implicitní souhlas s vykonáváním „černé práce“; v jeho chápání se jedná o součást pracovní náplně sociálního pracovníka. Informant dále vyjadřuje své přesvědčení, že právě výkon „černé práce" by měl být argumentem k zrovnoprávnění sociální práce s ostatními pomáhajícími profesemi. Vyjadřuje svůj zájem o prestiž profese sociální práce.

"Ten sociální pracovník nemůže být podhodnocenej. Naopak by měl mít stejnou úroveň jako ten učitel, nebo specialista, já řeknu psycholog, protože on dělá i tu černou práci. A to nikdo nevidí, že jo." (R12)

V poslední větě předchozí citace zaznívá povzdech, že tato „černá práce“ není vidět a může být ostatními členy týmu považována za méně důležitou než práce, kterou vykonávají oni. A právě tato skutečnost může přispívat k podceňování sociální práce jako praxe, ale zároveň vědecké disciplíny.

Rozdílné stanovisko zastává sociální pracovnice v pedagogicko-psychologické poradně, která připouští, že koná pouze administrativu a tím uvolňuje ruce dalším pracovníkům (především psychologům) k opravdové práci s klienty. Tuto svoji činnost však nepovažuje za sociální práci:

„Rozhodně si (pod sociální prací) představím něco jiného, než to, co dělám. To znamená větší kontakt s klientem, větší možnost mu pomoct, víc se seznámit s tím prrípadem, hledat cesty k řešení."(R13)

Tato pracovnice zároveň uvádí, že "ve spoustě organizací je ta pracovnice tak nějak upozaděná" a navrhuje osvětu, tedy "víc společnosti řikat, že opravdu jsou (sociální pracovníci) součástí systému a mají tam své právoplatné místo" (R13). Komunikační partnerka má vzdělání v sociální pedagogice, přesto disponuje jasnou představou o sociální práci a zdá se být se sociální prací i výrazně 
identifikována. Dané zjištění v tomto případě tedy nepotvrzuje náš předpoklad, že pro absolventy jiných oborů než sociální práce může být obtižné se se sociální prací identifikovat.

\section{Sociální pracovník jako prostředník mezi klientem (pacientem) a ostatními pracovníky multidisciplinárního týmu}

Zdravotně-sociální pracovníci, zejména vnemocnicích, které jsou charakterizovány výraznou hierarchičností, vnímají svoji roli rovněž jako prostředníka mezi zdravotníky a pacienty. Opakovaně jsme zaznamenali jejich postřeh o výrazné orientaci zdravotnických pracovníků čistě na zdravotní stav hospitalizovaného (R6 - R9).

S dominancí zdravotnické složky je konfrontována i sociální pracovnice v hospici, u níž tento aspekt dokonce vyvolává i představu jisté přebytečnosti v týmu:

„(Mám) otevřený dveře a prostě vidím, jak kolem procházejí ti pacienti nebo slyším někoho volat z toho pokoje, a protože tam zrovna nikoho nemám, tak se zvednu a jdu tam (...), nakouknete do jednoho pokoje, tam někdo spí, nakouknete do druhýho, tam se něco děje zdravotnickýho a nakouknete do třetího a už si pripadáte, že jste tam teda přebytečná." (R5)

Další z účastnic výzkumu si uvědomuje tlaky, kterým jsou lékaři vystaveni, a popisuje vlastní dilema. $\mathrm{Na}$ jedné straně má pro zdravotníky pochopení, na straně druhé ji př́lišná orientace pouze na jednu z dimenzí člověka ( $v$ tomto případě biologickou) komplikuje snahu o holistický prístup ke klientovi.

„Tlačí ho (lékaře) zdravotní pojištovna, je hnán tamtamy, je to tady o této stránce. A současně vy máte vykonávat tu sociální práci, která má toho člověka brát z té biosociální jednoty a vy už víte, že ta biologická stránka věci podle lékaře už je v pořádku, ale ta sociální spirituální jednotka ne."(R8)

Stejná komunikační partnerka dále popisuje subjektivně vnímanou nerovnováhu panující mezi kulturou organizace, v níž pracuje, a vlastní snahou o kvalitní výkon sociální práce. Její strategii bychom mohli označit jako akceptaci daných podmínek a zároveň úsilí o vykonávání co nejlepšího pracovního výkonu podle vlastního svědomí.

„Ale současně jste podřizen zdravotnickému zařizení, máte v uvozovkách nějaký príkaz, prostě aby se to někam dál hnulo, a ted's tím balancujete a snažíte se udělat to nejlepší." (R8)

Bariéra spolupráce je podle této pracovnice i na straně zdravotníků, kteří nejsou dobře orientováni ve zdravotnicko-sociálním systému poskytovaných služeb:

„A mnohdy ten lékař nemá takový přehled (...), že ten pohled není tak široký, jak ten zdravotně sociální pracovník může mít." (R8)

Ve výše uvedené citaci se objevuje důležitý aspekt. Zdravotně-sociální pracovnice si je vědoma toho, čím specifickým může přispět do vzájemné spolupráce; včem tkví jedinečnost jejího možného profesního př́nosu ve prospěch pacientů. Pohled lékařů dle jejích slov není tak široký, což může souviset s komplexním posouzením životní situace klienta, které je v kompetenci právě sociálních, zdravotně-sociálních pracovníků.

\section{Sociální pracovník na hraně mezi resorty}

Na začátku této subkapitoly ještě zůstaneme v oblasti zdravotnictví, nebot poukazování na resortní neprovázanost, $v$ tomto prípadě zdravotně-sociální oblasti, se ve výzkumných rozhovorech s pracovnicemi nemocnic objevovala opakovaně. Tato neprovázanost nepochybně zasahuje $\mathrm{i}$ do fungování multidisciplinárních týmů; komplikuje zejména proces vzájemného předávání informací, které jsou nezbytné k výkonu sociální práce.

„Myslím si, že se tady okolo řeší fưra věcí, ale myslím, si, že jádro pudla je v neprovázanosti zdravotního a sociálního systému. Tyhle dvě organizace mají spolupracovat, ale jim to zákon zakazuje. Já nemůžu 
předávat informace sociálním službám, sociální služby nesmí předávat informace mně, protože je to zakázáno."(R9)

Informantka tuto neprovázanost řadí k systémovým bariérám, které způsobují překážky v komunikaci mezi odborníky navzájem a mezi nimi a pacienty.

Sociální pracovník z uprchlického zařízení popisuje situaci, kdy jsou on a jeho kolegové z důvodu absence jiných možností nuceni poskytovat odborné služby nespadající na pole jejich profese. Překračují hranice oboru sociální práce.

„Ono je to komplikovaný v tom, že neumíme zabezpečit pružně a rychle péči o klienty s postižením. Že narážíme na nefunkční systém poskytování péče, v zařizeních péče a podobně, což je problém celé společnosti a u nás taky. Tím pádem to má dopad na všechny moje kolegy, kteří prostě pak musí situaci rešit v rámci toho zařizení vlastními silami. Musíme improvizovat. Vadí mi, že nejde prosadit součinnost některých složek, které třeba v této problematice mají personál, mají znalosti, ale jim to prostě neukládá zákon nebo nějaká zřizovací listina a v rámci našeho rezortu se prozatím s tím nedalo nic udělat." (R11)

Účastník výzkumu v předchozí citaci navrhuje, aby byla státem lépe garantována součinnost jednotlivých složek systému.

\section{Sociální pracovník mezi mlýnskými kameny v otázkách komunikace}

V této subkapitole se zaměříme na bariéry týmové spolupráce, které se týkají z pohledu sociálních pracovnic nevhodného způsobu zacházení s informacemi. V jednom z rozhovorů jmenovala informantka bariéru pozdního předání informací o pacientovi ze strany zdravotníků, které znesnadňuje výkon sociální práce „(...) mu nemůžeme nabídnout v tak krátký časový úsek tu péči, kterou bysme si představovali" (R7). Téže účastnici výzkumu znesnadňuje výkon sociální práce rovněž nepř́tomnost psychologů na oddělení: psychologové na pracoviště pouze dochází a nejsou k zastižení vždy, když by pracovnice jejich spolupráci potřebovala (R7). Její kolegyni ze stejného pracoviště (R8) brání v častější komunikaci v rámci multidisciplinárního týmu nárůst agendy, které se musí věnovat.

Další identifikovanou bariérou týkající se informací je jejich nedostatek potřebný pro výkon sociální práce, přičemž informantka je přesvědčena, že potřebné informace má pacient obdržet od lékaře. S nedostatkem informací souvisí tlak na rychlé vyřešení případu. Lékař nenaplňuje očekávání sociální pracovnice.

„Anonymní, tak anonymní. Je uspěchaná doba. Honí se pochopitelně doby hospitalizace (...) i obrovský peníze. Zkracuje (se) délka hospitalizace. Lékař trvá na tom, že pacient už je po akutní stránce doléčený, at' je posunut. Někam. Do léčebny. My víme, že na tu léčebnu bude čekat měsíc až dva, že je tady zbytečně. Ten lékař telefonuje a misto toho, aby se tady utvořila situace, pacient se posune bud' to směrem ošetřovatelským nebo směrem rehabilitačním nebo směrem sociálním, že by jasně uzavřel tu situaci a řekl nám, kam ten pacient má jit, tak nám řekne, hlavně at' odejde z hospitalizace. A to nám stěžuje práci. Ten lékař je gró všeho, který má říct, kam s pacientem, kam to budeme směřovat. "(R6)

Další překážku v mezioborové spolupráci nazvala stejná informantka bariérou nevyřknutých informací (R6). Jedná se o opakující se podezření, že lékař nesdělil pacientovi celou pravdu o jeho zdravotním stavu, což patří mezi jeho kompetence: „Nemyslím tím vyloženě jakoby zatajení, ale prostě nedořeknutí něčeho. Což já ze své pozice nemůžu udělat, ale ten, kdo k tomu jakoby je oprávněn (lékař), tak to třeba nedořekne. Pak to moje jednání vůči tomu pacientovi se mi zdá, že trošku tak jakoby mu v podstatě něco zatajuju, Ižu“ (R6).

Informantka poukazuje na limit svých kompetencí, kdy není oprávněna sdělovat informace o zdravotním stavu pacienta, a pritom by na pravdivé a reálné informace potřebovala navázat ve výkonu intervence sociální práce. 
Někdy absence žité každodenní zkušenosti jiného pomáhajícího pracovníka může v očích sociálního pracovníka z pobytového zařízení vyvolat konflikt, jak popisuje pracovnice dětského domova.

„A máme děti, který řeknou ,prijiedu ve čtyři' a telefonují o půl desáté, sháníme je (...) a řeknu jim, kde jseš, já pro tebe prijedu', a oni řeknou ,neřeknu, kde jsem'. No a prijiedou o půl jedenácté. Takže potom tam třeba se setkáme s tím, že pokud tady ta slečna řekne, já bych chtěla na vycházku, já chcu jít...', já nevím kam, tak jí řekneme ,ne, nikam nepůjdeš’. A pak nám zavolá paní psycholožka a řekne, že ona už je velká, a že nechápe, proč ji nepustíme. "(R10)

Do nesouladu se dostává autonomie klientky, kterou prosazuje psycholožka, s potřebou zajištění bezpečí (klientky i sociální pracovnice), což na základě zkušenosti preferuje sociální pracovnice.

\section{Diskuse}

Nyní bychom rádi výsledky našeho výzkumu stručně komparovali s teoretickými kořeny z teoretické části. Autoři Shore et al. (2011) inkluzi charakterizují jako stav, kdy je jedinec považován ve své pracovní skupině za insidera a má saturovanou potřebu sounáležitosti a zároveň vlastní jedinečnosti. Výsledky našeho výzkumu prokázaly, že tohoto stavu není v sociální práci často dosaženo a sociální pracovník někdy nedělá sociální práci. Sociální pracovníci jsou leckdy v týmu těmi, kteří vykrývají práci neobsazenou jinými profesionály (srov. Wiles \& Vicary, 2019). Mnohdy se jedná o práci nevyžadující odborné znalosti. Tato skutečnost je vrozporu sinkluzivním požadavkem rovnoprávnosti zainteresovaných profesí v multidisciplinárním týmu. Rovnoprávností pritom myslíme možnost přispět do spolupráce tím, na co mám odbornost a nikoliv tím, co nechce (nebo nemůže) dělat zástupce jiné profese. Multidisciplinární týmy mohou fungovat jaksi "automaticky“ v souladu s kulturou dané organizace a jednotliví členové (či manažer) se leckdy ani nezamýšlí nad možnými změnami, které by pružněji reagovaly na nové vědecké poznatky.

Dané potvrzuje Simpkin (2005) když o oblasti zdravotnictví píše, že změna vědění, spočívající k příklonu k holistickému pohledu na nemoc a zdraví, vyvolává potřebu změny modelu organizace práce lékařu a sociálních pracovníků. Pokud je úkolem lékařu léčit nemocné a uznáváme, že při léčbě je třeba brát v úvahu nejen biomedicínské, ale také psychosociální faktory uzdravování, pak musí lékaři přijmout účast na rozhodnutích, jež se vymykají oblasti jejich navyklé suverénní kompetence. Hierarchické uspořádání rozhodování jejich spolupráce se sociálními pracovníky by proto mělo být nahrazeno vzájemným uspořádáním. Popisované souvisí s nastavenou kulturou organizace v nemocnicích, které jsou charakteristické výrazným hierarchickým upořádáním. Toto Simpkinovo doporučení však vyžaduje kromě modifikace kultury organizace i zažitou změnu smýšlení - jak lékařů, tak sociálních pracovníků.

Stejný autor (Simpkin, 2005) potvrzuje výsledky našeho výzkumu, kdy k mezioborové spolupráci v oblasti zdravotnictví uvádí skutečnost, že lékaři nejsou zvyklí konzultovat svá rozhodnutí s lidmi mimo svůj obor. Sociální pracovníci jsou naopak podle stejného autora zvyklí pohybovat se v byrokratických organizacích a považují proto za přirozené být při rozhodování vedeni. Identifikace lékařů i sociálních pracovníků se zvyklostmi jejich oboru proto brzdí změnu modelu rozhodování, která by odpovídala změně vědění o nemocech. Jak ukázaly výsledky našeho výzkumu, nemohou z výše uvedených důvodů sociální pracovníci pracovat holisticky, i když právě holistický přístup je tím, co odlišuje sociální pracovníky od pracovníků ostatních pomáhajících profesí (Musil, 2004).

Potvrdily se také poznatky Clarka (2000) o tom, že sociální práce musí každodenně obhajovat svoji existenci a vyvracet pochybnosti ohledně svého vlastního účelu a metod využívaných $v$ praxi. Informanti opakovaně zprostředkovávali svoje zkušenosti s náhledem lidí stojících mimo sociální práci na sociální práce spočívající v znevažování této profese. A ověřili jsme i tezi Venglářové a kol. (2011) o tom, že bariérou v týmové práci může být i to, že pracovník má jiná očekávání od pracovní pozice. Jedna z informantek (R13) např. poukázala na skutečnost, že na dané pracovní pozici nemůže vykonávat činnosti, které jsou z jejího pohledu součástí sociální práce, což zároveň dokládá i tvrzení 
Truhlářové (2013), že neexistuje jediná všeobecně platná taxonomie profesionálních kompetencí sociálního pracovníka. Zatímco R12 považuje "černou práci“ za součást pracovní náplně sociálního pracovníka, R13 s takto nastaveným obsahem práce nesouhlasí.

\section{Závěr}

V úvodu jsme si položili otázku: Jaké bariéry inkluze do multidisciplinárních týmů popisují vybraní sociální pracovníci?

Jednou z bariér inkluze sociálních pracovníků do multidisciplinárních týmů může být postoj samotných sociálních pracovníků, kteři akceptují roli pomocníka ostatních a vykonávajících „„̌ernou práci“, na kterou není potřeba odborné specializace. Jindy zase sice vykonávají odbornou práci, při níž ale suplují činnost jiných služeb a tato práce nespadá na pole sociální práce. Sociální pracovníci, jak jsme zaznamenali v jejich odpovědích, mnohdy sami neusilují o změnu tohoto stavu; možná i proto, že jsou i ve svém okolí konfrontováni se znevažováním profese sociální práce. Jen určití informanti reflektovali svoje postavení a z toho jen někteří měli snahu s tím něco dělat. Vybraní účastníci výzkumu si uvědomují svůj specifický př́nos, kterým mohou do fungování multidisciplinárního týmu přinést. Ten ale ne vždy mohou uplatňovat, nebot' např. nemají možnost pracovat $\mathrm{s}$ informacemi potřebnými $\mathrm{kjejich} \mathrm{intervenci.}$ Cíle práce sociálních pracovníků nejsou vždy totožné s cíli pracovníků dalších pomáhajících profesí (nebo mají další odborníci jiný názor, jak se dostat k cíli); dochází ke střetu, v němž jsou leckdy cíle stanovené sociálním pracovníkem upozaděny. Sociální pracovníci se setkávají se skutečností, že jejich názor na životní situaci klienta není v multidisciplinárním př́stupu dostatečně reflektován

Bariéry inkluze sociálních pracovníků do multidisciplinárních týmů souvisejí s identitou profese a nízkou prestiží sociální práce. a problémy $v$ začleňování způsobují i bariéry mezi resorty, kdy nefunguje součinnost jednotlivých složek systému. Všímali jsme si i rozdílných očekávání členů multidisciplinárních týmů od spolupráce. Např. očekávání sociálních pracovníků od lékařu jsou poměrně jasná, ale zdá se, že ne vždy ze strany sociálních pracovníků komunikovaná směrem klékařům. Mnohdy nedokáží prosadit své zájmy, jejichž prostřednictvím hájí zájmy svých klientů. Výsledky našeho výzkumu poukazují na skutečnost, že někteří sociální pracovníci, účastníci výzkumu, se přizpůsobují očekávání druhých.

Závěrem bychom rádi předložili náměty na další výzkumy v dané oblasti. Domníváme se, že by bylo vhodné přinést ucelený přehled možných bariér týmové multidisciplinární spolupráce sociálních pracovníků. Ty by bylo možné lépe identifikovat při zaměření na jednu ohraničenou oblast sociální práce (např. školské sociální práce nebo sociální práce ve zdravotnictví). Další neprobádanou oblastí je příprava budoucích sociálních pracovníků (různých kvalifikačních oborů včetně sociální práce) na práci v multidisciplinárních týmech. Možnosti spolupráce sociální pedagogiky a sociální práce by mohl projasnit výzkum zaměřený na postoj akademiků a výzkumníků z oblasti sociální pedagogiky k sociální práci jako akademické i praktické disciplíně (a naopak). Pozornost výzkumných pracovníků by mohla být orientována i na obsahy kvalifikačního vzdělávání sociálních pracovníků mimo mateřské obory.

\section{Literatura}

Asociace vzdělavatelů v sociální pedagogice. (2019, ř́jen 15). Standardy vzdělávání v sociální pedagogice pro jednotlivé typy studijních programů vydané Asociací vzdělavatelů v sociální pedagogice. Dostupné z http://asocped.cz/folders-1305/

ASVSP. (2019, červenec 15). Minimální standard vzdělávání v sociální práci ASVSP. Dostupné z http://www.asvsp.org/standardy.php 
Bartoňová, M., \& Vítková, M. (2016). Inkluze ve škole a ve společnosti jako interdisciplinární téma. Brno: Masarykova univerzita.

Clark, C. L. (2000). Social work ethics. Politics, principles, and practice. London: Macmillan Press.

Gulová, L. (2011). Sociální práce pro pedagogické obory. Praha: Grada.

Hladík, J. (2019, ř́jen 15). Vyjádření k pracovnímu dokumentu pro tvorbu věcného záméru zákona o sociálních pracovnících (Konzultační dokument MPSV pro období červen až záŕí 2014). Dostupné z http://asocped.cz/folders-1305/

IFSW. (2019, červenec 15). Global definition of social work. Dostupné z http://ifsw.org/getinvolved/global-definition-of-social-work

Kaplánek, M. (2013). Sociální pedagogika a sociální práce. In O. Matoušek a kol., Encyklopedie sociální práce (s. 503-506). Praha: Portál.

Kraus, B. (2011). Paradigmata sociální práce a sociální pedagogiky. In Marášková, I. (Ed.), Politiky a paradigmata sociální práce: Co jsme zdědili a co s tím uděláme? Sborník z konference (s. 27-35). Zlín: Univerzita Tomáše Bati ve Zlíně.

Kraus, B., \& Hoferková, S. (2016). Ke vztahu sociální pedagogiky a sociální práce. Sociální pedagogika / Social education, 4(1), 57-71. Dostupné z http://soced.cz/wpcontent/uploads/2016/04/STUDIE-SocEd_Ke-vztahu-soci\%C3\%A1In\%C3\%AD-pedagogiky-asoci\%C3\%A1ln\%C3\%AD-pr\%C3\%A1ce.pdf

Musil, L. (2004). „Ráda bych vám pomohla, ale..." Dilemata práce s klienty v organizacích. Brno: Marek Zeman.

Musil, L. (2013a). Challenges of postmodern institutionalisation for education in social work. In T. Matulayová, \& L. Musil, Social work, education and postmodernity. Theory and studies in selected Czech, Slovak and Polish issues (s. 10-72). Liberec: Technical University of Liberec.

Musil, L. (2013b). Identita oboru / profese sociální práce. In O. Matoušek a kol., Encyklopedie sociální práce (s. 512-513). Praha: Portál.

Nečasová, M., \& Křištáan, A. (2018). Social work in the Czech Republic : Conformist or critically engaged? In C. Nieto Morales, \& M. Solange de Martino Bermúdes, Social work in XXI. century St. Challenges for academic and professional training (s. 44-57). Madrid: Dykinson.

Nečasová, M., Dohnalová, Z., \& Rídlová, R. (2012). User of social services in postmodern times. Sociální práce / Sociálna práca, 12(5), 13-23.

Němec, J., \& Šíp, R. (2013). Manifest sociální pedagogiky. Sociální pedagogika / Social Education, 1(1), 5-17. Dostupné z http://soced.cz/wp-content/uploads/2014/04/ManifestSoci\%C3\%A1 ln\%C3\%AD-pedagogiky.pdf

NHS England/Nursing/LTC. (2014). Multi-disciplinary team handbook. Leeds: NHS England.

Přadka, M. (2002). Koncepce výchovy ve volném čase. In J. Němec a kol., Kapitoly ze sociální pedagogiky a pedagogiky volného času pro doplňující pedagogické studium (s. 15-26). Brno: Paido.

Shore, L., Randel, A., Chung, B., Dean, M., Holcombe Ehrhart, K., \& Singh, G. (2011). Inclusion and diversity in work groups: A review and model for future research. Journal of Management, 4, 1262-1289.

Simpkin, M. (2005). Holistic health care and professional values. In S. Shardlow (Ed.), The values of change in social work (pp. 57-76). London: Tavistock/Routledge.

Společnost sociálních pracovníků ČR. (2019, ř́jen 15). Etický kodex Společnosti sociálních pracovníků. Dostupné z http://socialnipracovnici.cz/public/upload/image/eticky_kodex_sspcr.pdf

Šíp, R. (2013). Nové paradigma vědy, nové paradigma pedagogického výzkumu. In L. Gulová, \& R. Šíp (Eds.), Výzkumné metody v pedagogické praxi (s. 12-37). Praha: Grada. 
Dohnalová, Nečasová, \& Trbola / Vybrané bariéry inkluze sociálních pracovníků ...

Truhlářová, Z. (2013). Kompetence v sociální práci. In O. Matoušek a kol., Encyklopedie sociální práce. (s. 516-518). Praha: Portál.

Venglářová, M. a kol. (2011). Sestry v nouzi. Syndrom vyhoření, mobbing, bossing. Praha: Grada.

Webb, S. A. (2017). Matters of professional identity and social work. In S. A. Webb (Ed.), Professional identity and social work (s. 1-18). London: Routledge.

Wiles, F., \& Vicary, S. (2019). Picturing social work, puzzles and passion: Exploring and developing transnational professional identities. Social Work Education, 38(1), 47-62.

Zákon č. 108/2006 Sb., Zákon o sociálních službách. (2019, červenec 15). Zákony pro lidi. Dostupné z https://www.zakonyprolidi.cz/cs/2006-108

Zákon č. 563/2004 Sb., Zákon o pedagogických pracovnících a o změně některých zákonů. (2019, červenec 15). Zákony pro lidi. Dostupné z https://www.zakonyprolidi.cz/cs/2004-563 